\title{
COMMENTS
}

\section{THE PAROL EVIDENCE RULE: A CONSERVATIVE VIEW}

\author{
"There is no magic in the writing itself."
}

\section{Wigmore*}

This is an attempt to describe the parol evidence rule; to show that it is only because there is magic in the writing that the rule exists; and to show that the rule is a restatement of the objective theory of contract interpretation. Since the cases in Illinois represent as well as any the operation of the rule, they have been selected as the basis for this inquiry.

\section{I}

Every exclusion of evidence resulting from the application of the parol evidence rule presupposes at least that the writing is binding upon the parties. An instrument cannot be legally operative until it has been delivered ${ }^{2}$ and delivery depends not upon the transfer of possession but upon the intent of the parties. ${ }^{3}$ Since it is not ordinarily possible to determine whether the parties intended to deliver the document by an examination of the writing, it is necessary that delivery be established by parol. But this is not an exception to the parol evidence rule. The issues are not the same. The delivery issue is whether an instrument is to have legal significance. The issue for the parol evidence rule is the amount of significance to be given to the writing.

It is also erroneous to conclude that the delivery question is not related to the parol evidence rule. The relationship results from a distinction used to determine whether an oral agreement, prescribing a condition to be fulfilled before the parties are to be bound and made at the time the instrument is manually delivered, ought to be considered. The distinction is that a condition to be performed before the instrument is considered delivered may be shown, but a condition to be performed before the agreement is binding and after delivery may not be shown. 4 While this distinction is merely a restatement of the difference between the subject matter of the delivery doctrine and the parol evidence rule,

* 9 Evidence $\$ 2400$ (3d ed., I940) at 5.

I Fisk Tire Co. v. Burmeister, 252 Ill. App. 545 (I929).

2 Ryan v. Cooke, 172 Ill. 302, 5o N.E. 213 (I898); Jordan v. Davis, ro8 Ill. 336 (r884). For a discussion of the development of this doctrine see 9 Wigmore, Evidence $\S 2405$ (3d ed., I940).

3 Jordan v. Davis, Io8 III. 336 (I884).

4 Ibid.; Ryan v. Cooke, I72 Ill. 302, 50 N.E. 213 (I898); Stanley v. White, I60 Ill. 605, 43 N.E. 729 (1896); 9 Wigmore, Evidence $\$ 2410$ ( 3 d ed., I940) at 35. For negotiable instruments, the distinction has been made in terms of a conditional delivery as opposed to a conditional payment. Larson v. Lybyer, 3r2 Ill. App. I88, 38 N.E. 2d I77 (194r); State Bank of West Pullman v. Hovnanian, $25^{\circ}$ Ill. App. I44 (I928); Handley v. Drum, 237 Ill. App. $5^{87}$ (r925). 
and although it is theoretically accurate, it has been difficult to apply. Inasmuch as the inquiry for the courts is directed toward the intent of the parties, and the parties intend in both situations not to be bound by the terms of the instrument until a condition is performed, the imposition of a determining factor (the intent to pass present title to the writing) ${ }^{5}$ not considered by the parties can only lead to conflicting results.

Not every case in which the delivery problem is at issue involves a condition. It is not difficult to decide, for example, that a contract given to another for display is not to be considered as delivered. ${ }^{6}$ For purpose of analysis, cases involving a condition appear to fall into two groups. One is composed of instruments which are printed forms. The other is composed of instruments which have been prepared by the parties. The courts have found little trouble in permitting a party to show that a term in a printed form was to be altered before he was to be bound. ${ }^{7}$ It is the situation in which the instrument is not a printed form and conceded to be the ultimate obligation of the parties but was not to become binding until the performance of an extrinsic condition that has presented the problem.

The condition has taken two principal forms. One is the necessity of approval by a third party, and it is the subject matter of Curtis v. Harrison ${ }^{8}$ and Ryan v. McArdle. 9 The other is the necessity of a contract between one of the parties and a third person, and it is the subject matter of Jordan v. Davis ${ }^{\mathrm{ro}}$ and Ryan v. Cooke. .I

5 While this is not the familiar way to describe the factor, several Illinois decisions contain this language. See, e.g., Stanley v. White, 160 Ill. 605, 43 N.E. 729 (1896).

${ }^{6}$ See Khosrovschahi v. Goldberg, 333 Ill. App. 378, 77 N.E. 2d 569 (I948).

7 A form providing for the guarantee of an unlimited amount of credit was to be limited to a maximum of four hundred dollars. Fisk Tire Co. v. Burmeister, 252 IIl. App. 545 (Ig29). A form providing for the delivery of the purchased goods "within four month" was to be changed to "as needed." The court reluctantly permitted the agreement to be shown, declaring that "in doing so, we are of the opinion that there is not much left of the parol evidence rule. . . " Northwestern Consolidated Milling Co. v. Sloan, 232 Ill. App. 266, 27I (I924).

${ }^{8} 36$ Ill. App. 287 ( 1889 ). The defendant signed a contract for the erection of a monument and subsequently notified the plaintiff-seller not to perform. The defendant offered to prove that the delivery of the contract was conditional upon the approval of her children.

${ }^{2}$ I59 Ill. App. 579 ( $\mathrm{rgI}$ ) . The defendant lessee, having signed a lease, offered to show as a defense to his breach an agreement that the lease was to be approved by a third person before the lessee was to be bound and that this assent was never given.

10 $108 \mathrm{Ml} .336$ ( 1884 ). The plaintiff, claiming to be the sole lessee, brought an action of forcible detainer against the defendant who occupied the premises and who also claimed to be the sole lessee. The court found that the lease under which the defendant claimed was drawn with the understanding that the defendant was to procure the endorsement of a third person as guarantor for the rent before the lease was to be binding; that the defendant notified the owner concerning the impossibility of procuring the signature; and that the owner then leased to the plaintiff.

${ }^{11}{ }_{12}$ IIl. 302 , 50 N.E. $2{ }_{3}$ ( 1898$)$. Under a patent-licensing agreement, the defendant licensee refused to manufacture the required minimum number of items upon which he was to pay a royalty. The licensee offered to show an oral agreement that he was not to be bound until he procured a contract from the city of Chicago which he failed to do. 
In the Curtis case the defendant contended that the delivery of the contract was not to take effect until the contract had been approved by specified persons and that it was agreed that the plaintiff would take the contract to them but had not done so. Proof of this contention was admissible. In the $M c A r d l e$ case, the court quoted the defendant as offering to prove "[ $t]$ hat at the time of the signing of this contract [it was agreed] that this contract should not become effective until it was approved by [a third person], and that assent was never given, and therefore the contract was never delivered." ${ }_{22}$ This offer of proof was rejected. Despite the fact that both defendants sought to achieve the same end, that is, to keep the contract inoperative until the performance of the same condition, the language utilized by counsel was so important to the court that it failed to determine adequately the only basis it had for resolving the delivery issue-the intention of the parties. The difference between contending that the delivery was conditional and that the obligation was conditional was all that was required to produce contrary results from the same facts.

In the Jordan case, a completed lease was signed and left with the lessee under an agreement that it should not become binding until the lessee found a guarantor to sign the lease. The plaintiff's counsel asked that the jury be instructed "that the [lease] was not to become a binding contract between the

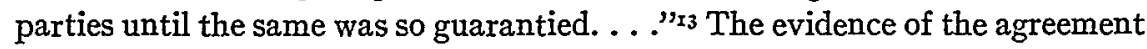
was admissible. In the Cooke case, it was understood that a contract was not to become binding until the defendants obtained a contract from a municipality. The evidence of the agreement was not admissible..$^{x_{4}}$ It cannot be said that there is a difference in the language of the contentions here.

The Jordan case and the Curtis case are examples of agreements to keep the contract inoperative until the performance of a condition. The agreements have been admitted because the courts found a condition to be performed precedent

22 Ryan v. McArdle, 159 Ill. App. 579, 583 (I9Ir).

${ }_{3}$ Jordan v. Davis, 108 Ill. 336,340 (1884). The defendant asked for the following instruction: "That if the jury believe ... that the lease . . . was executed by [the parties], and unconditionally delivered ... then such lease was not made . . . upon condition that [the lessee] would procure [the third party] to guaranty the payment of the lease; that no such condition is found in the lease, and no verbal agreement to give such guaranty, if made prior to the execution of the lease, would be of any effect as against the terms of the lease." Ibid., at 34r. The court believed that "[t]his instruction, as applied to the facts in the case, was false and misleading. ... This instruction carried the wrongful idea to the jury that the condition ... to be of avail, should have been embodied in the lease. . . The verbal agreement for the lease was not offered in contradiction of the terms of the lease, but to disprove delivery. The question of delivery is something aside from the writing in an instrument." Tbid., at 342.

14 The defendants had in fact pleaded that the verbal agreement was made after the delivery of the contract but on the same day. Neither the parol evidence rule nor the delivery doctrine is applicable to agreements made subsequent to delivery, and the entire discussion of the case by the court would be meaningless unless the agreement is considered to be contemporaneous with the execution of the document. For other examples of the temporal scope of "contemporaneous" see cases cited note 35 infra. Without any analysis of the intention of the parties, the court simply declared that the "delivery of the contract ... is established beyond question, and there is no evidence of a conditional delivery of the same." Ryan v. Cooke, I72 Ill. $3 \circ 2,3 \circ 9,5 \circ$ N.E. $21_{3}, 2{ }_{5}$ (1898). 
to delivery. The McArdle and Cooke cases are also examples of agreements to keep the contract inoperative until the performance of a condition. But these agreements have been rejected because they show a condition to be performed subsequent to delivery. Yet there is no difference in the "non-legal" intent of the parties or in the conditions. And while it can be said that there is at times a difference in the language used by the parties to describe the function of these conditions, the difference does not always exist, so that it cannot be the distinguishing feature and is of no help in deciding these cases. Since the theoretical distinction between the subject matter of the parol evidence rule and the delivery doctrine is sound, it is not readily apparent why these cases should cause so much difficulty. ${ }^{15}$

When a sound distinction is applied and the resulting decisions are in conflict, it would seem to indicate that the facts which are important to the court can be as easily described by one concept as the other. But any distinction implies that there is at least one fact which is necessarily present in one concept and not in the other. The fact which distinguishes the subject matter of the parol evidence rule from that of the delivery doctrine is the "intent" of the parties to pass a present title to the instrument. This fact, which the courts admit to be the object of their inquiry, cannot be adequately determined because the parties do not frame their intention in those terms. It is likely that the confusion will continue.

The persistence of the confusion is a confession that the maintenance of the distinction is more important than the results of its application. The importance of searching for an illusory and generally nonexistent fact must be explained by the importance of the basis of the distinction. The basis can be discovered by restating the distinction in terms of the obligation of the parties. In those terms, the difference is between an intention not to be bound by the writing, as opposed to an intention to be bound by the writing but not by the obligation. To make sense of this restatement it is necessary to believe that the writing has significance apart from the actual obligation of the parties. Since the intent with respect to the writing, rather than the intent with respect to the obligation, is decisive for the admissibility of parol agreements, it is now clear that not only has the writing a significance of its own but delivery makes the writing more important than the actual obligation. So the conclusion must be that it is the magic of the writing which forms the basis of the distinction, makes the search for illusory and often nonexistent facts important, and is responsible for the persistent confusion. ${ }^{26}$

The most conclusive test of the magic of the writing is the situation in which an oral agreement that would clearly show a conditional delivery competes with a writing that denies the existence of the condition. The test is conclusive because no writing can do more than predict an intention of the parties which

${ }^{25}$ Nor is it apparent why it should make a difference that an instrument is in printed form.

${ }^{16}$ With respect to printed forms, all that can be said at this point is that their significance apart from the actual obligation is not as magical as that of writings drafted by the parties. 
will exist after the document has been drawn, and delivery must necessarily follow the execution of the writing. Yet the oral agreement cannot be shown.

The defendant and forty-four others in Chicago Title \& Trust Co. v. Cohen ${ }^{17}$ had signed a written guarantee for the payment of bonds issued by a borrower to a lender to secure a loan. The maker defaulted. The defendant offered to show that the contract of guarantee was delivered upon the condition that it was not to be binding until executed by additional parties. It was conceded that the defense, if accepted, would show a conditional delivery. Yet the offer was rejected because the court found the writing to be inconsistent with the contention. While there was no provision in the contract which conflicted with the condition, the inconsistency was inferred from the fact that all forty-five individuals named as parties of the first part in the contract had signed the document..$^{8}$

Since ordinary notions about delivery would have decided the Title \& Trust case in a contrary manner, the court has conclusively confirmed the existence of the magic by considering it the determining factor in the situation where the magic is least likely to exist.

The delivery doctrine has served as the initial step because it has reflected the fundamental concept of the parol evidence rule. The concept is the magic of writing. .

\section{II}

The significance of writing is the principal notion of the parol evidence rule. The legal concept reflects the purpose of an everyday commercial practice. The practice is to reduce oral agreements to writing. If the parties were confident that the oral agreement would be performed, there would be no need to reduce it to writing. So the anticipation of a possible breach and future litigation is responsible for the practice.

The function of writing in litigation is to provide a basis for determining the obligation of the parties. ${ }^{x 9}$ Since the obligation could have been determined by oral testimony, ${ }^{20}$ the decision to reduce the oral agreement to writing means

${ }^{27}{ }_{284}$ Ill. App. I8I, I N.E. $2 \mathrm{~d} 7 \mathrm{I}_{7}$ (I936).

${ }^{18}$ The plaintiff contended and apparently the court agreed that while "conditional deliver may be shown outside the language of the contract... [if] the contract on its face denies the existence of any such condition, or where by necessary implication such condition is impossible, then to permit parol proof to the contrary would not only vary but destroy the agreement." Tbid., at 194, 722. This point is implied in Cannon v. Michigan Mutual Life Ins. Co., I03 Ill. App. 4I4 (r902) in which the oral agreement was offered to show that a written condition for delivery within the contract was not operative.

I9 This function of writing is of recent origin. The early history of the magic of writing shows a distinct distrust of everything written, which may be viewed as a consequence of widespread illiteracy. See 9 Wigmore, Evidence $\$ 2426$ (3d ed., I940).

${ }^{20}$ The law has placed some restrictions upon this method of proof by virtue of such legislation as the statute of frauds. The transfer of property interests requires a written instrument, and parol agreements are not binding unless they have been partially executed. So the resort to writing for this purpose is not relevant to the parol evidence rule. If there were no statute of frauds, the parol evidence rule would not forbid the proof of many oral agreements for the transfer of property. The clearest case wou ldbe a completely oral agreement. 
that the parties prefer to rely on the writing. It is a decision that the writing is to be the best evidence of their agreement.2x

The recognition of this function eliminates the controversy between those who contend that the writing is only the best evidence of the terms within it and those who contend that it is the best evidence of the entire agreement. It is clear that a legal obligation can be altered as significantly by changing a written term as by adding another one. Since the only reason for executing the document is to make certain that the obligation is determined by the writing, the writing must be considered the best evidence of the entire agreement. Thus it should not make a difference to the court whether a party offers to prove a prior agreement to alter an existing term or add another. Because both would vary the written obligation, neither should be admitted.22

This is the basis for the magic of the writing. Transformed into a legal concept, it is the parol evidence rule which declares evidence of prior agreements inadmissible to alter a writing that contains a complete legal obligation. The process for the court is to determine whether the writing has sufficient terms to describe a complete legal obligation. ${ }^{23}$ If it does, the court must decide that it represents the entire expression of the agreement. Several decisions contain an accurate statement of the rule. ${ }^{24}$ Yet despite the variety of ways to describe the rule, the results have been consistent with this fundamental formulation. ${ }^{25}$

${ }^{2 x}$ But see Wigmore's comment that "the rule is in no sense a rule of Evidence, but a rule of Substantive Law. It does not exclude certain data because they are for one or another reason untrustworthy or undesirable means of evidencing some fact to be proved." 9 Wigmore, Evidence $\$ 2400$ ( 3 d ed., I940) at 3 .

2 Since a parol agreement is promissory in nature, it can only seek to change the promissory language of the writing. Nothing involved in the parol evidence rule could preclude alteration of factual statements found to be untrue. Thus, it is a common rule that receipts can be altered by parol evidence. Starkweather v. Maginnis, I96 Ill. 274, 63 N.E. 692 (I902); Richardson v. Hadsall, ro6 Ill. 476 (I883); White v. Merrell, 32 Ill. 5II (I863). Similarly, receipts within contracts can be varied but not the promissory language. Hossack v. Moody, 39 Ill. App. 17 ( 1890 ); Andrus v. Mann, 92 Ill. 40 ( 1879 ). This notion is applied to recitals of consideration. Spence v. Central Accident Ins. Co., 236 Ill. 444, 86 N.E. ro4 (rgo8) (insurance policy); Ludeke v. Sutherland, 87 Ill. 48 I (I877) (deed). Attempts have been made to show parol agreements by alleging them to be part of the consideration recited, which may be varied, but the attempts have been properly rejected. Hagen v. Lehmann, 3 I 7 Ill. 227, I48 N.E. 57 (I925). But cf. Metzger v. Emmel, 289 IIl. 52, 124 N.E. 360 (I9x9).

${ }^{23}$ This is not the ordinary way in which the rule is described. See, e.g., Greene, Theories of Interpretation in the Law of Contracts, 6 Univ. Chi. L. Rev. 374 (r939). Yet the Illinois decisions have usually adopted this language. See cases cited note 24 infra.

21 Ginsburg v. Warczak, 33 o Ill. App. 89, 69 N.E. 2d 733 (x946); Armstrong Paint Works v. Continental Can Co., 301 Ill. I02, I33 N.E. 7 II (I922); North Shore Lumber Co. v. South Side Lumber Co., 176 Ill. App. 96 (IgI2); Fuchs \& Lang Co. v. Kittredge \& Co., 242 Ill. 88, 89 N.E. 723 (I $9 \circ 9$ ); Osgood v. Skinner, 21 I Ill. 229, 7I N.E. 869 (I9०4); Telluride Power Co. v. Crane Co., 208 Ill. 2I8, 70 N.E. 3 Ig (Ig04); Union Special Sewing Machine Co. v. Lockwood, r ro Ill. App. 387 (rgo3); Keegan v. Kinnaire, I2 Ill. App. 484 (r882).

${ }^{25} \mathrm{~A}$ good indication of the confusion surrounding the rule is the insertion in a contract of a provision declaring that no agreements other than those in writing have been made. If the writing is complete, other agreements cannot be shown and if incomplete, they must be shown. Some courts have not referred to the clause in their decisions. Lyon \& Healy, Inc. v. Central States Hotel Co., 296 Ill. App. 245, I6 N.E. 2d $r_{55}$ (I938) (parol evidence admitted for an incomplete writing); Smith v. Rust, 310 Ill. App. 47, 33 N.E. 2d 723 (r94I) (parol evidence in- 
The analysis of the other statements of the rule depends upon the development of two aspects of the rule. The first is the class of agreements which brings the rule into operation. When the rule is operative, the second aspect relates to those agreements which are excluded by the rule.

The magic of the writing is a legal concept based upon the intention of the parties to have their obligation determined by the writing. The implication is that the writing must contain enough terms to constitute a complete obligation. When it does not, parol testimony must furnish the missing terms. ${ }^{26}$ The plaintiff in Van Kirk v. Scott ${ }^{27}$ sought to recover for breach of an employment contract. The only written evidence of the agreement was as follows: "Will draw at the rate of $\$ 3,75^{\circ}$ per annum. If J. D. C. V. incapacitates himself for business by intemperance, his salary will be stopped until he shows himself to be fully recovered and fit for business to the satisfaction of C., P., S. \& Co.", 28 The court found the memorandum "totally incapable of interpretation or of enforcement" and thus found it necessary to receive parol testimony to determine the contract. ${ }^{29}$ But the magic of writing is not always displaced because of an incomplete writing. Whenever the missing term may be implied as a matter of law, the writing is treated as if it were complete. ${ }^{30}$ Thus for example,

admissible for a complete contract). Others have declared it binding when the writing was complete, Metropolitan Life Ins. Co. v. Schwarz, 3 Io Ill. App. 205, 33 N.E. 2 d 934 (194I), and not binding when the writing was incomplete, Air Conditioning Corp. v. Honaker, $296 \mathrm{Ill}$. App. 22r, I6 N.E. 2d I53 (I938).

${ }^{26} \mathrm{~A}$ written instrument in the form of an incomplete obligation cannot perform its function. So it is no longer possible to reason from this function in order to prohibit a party from showing an agreement contrary to a written term. Yet an unambiguous written term may not be altered. For a case in accord with this last proposition see Carlton v. Smith, 285 Ill. App. 380 , 2 N.E. $2 d$ Ir6 (1936). See also Meyer v. Sharp, 34I Ill. App. 43I, 435, 94 N.E. 2d 5IO, 5I2 (I950); Offenberg v. Arrow Distilleries Co., 222 Ill. App. 512, 5 ×6 (I912); Durham v. Lathrop, 95 Ill. App. 429, 433 (r900); Fuchs \& Lang Co. v. Kittredge \& Co., 242 Ill. 88, 89 N.E. 723 (Igog); Sabo v. Nimett, I78 Ill. App. 459 (I9I3).

${ }^{27} 54$ Ill. App. 68r (I894).

${ }^{28}$ Ibid., at 684 .

29 Ibid., at 685 . For other examples of the admissibility of parol evidence to supplement incomplete writings, see Meyer v. Sharp, 34I Ill. App. 43I, 94 N.E. 2d 5 ro (I 950); Foerster v. L. Fish Furniture Co., 265 Ill. App. 4ro (1932); Durham v. Lathrop, 95 Ill. App. 429 (1900); Millers' Nat'l Ins. Co. v. Kinneard, 35 Ill. App. I05 (1889); St. Clair County Benevolent Society v. Fietsam, Adm'r, 97 Ill. 474 (1881); Offenberg v. Arrow Distilleries Co., 222 Ill. App. 512 (I92I); Bross v. Cairo and Vincennes R. Co., 9 Ill. App. 363 (I88I).

$3^{\circ}$ Davis v. Fidelity Fire Ins. Co., 208 Ill. 375, 70 N.E. 359 (Ig04); Union Special Serving Machine Co. v. Lockwood, rro Ill. App. 387 (1903). There is a second line of cases involving an implication of law which prohibits the introduction of evidence to show a parol agreement contrary to the implication. These cases involve a written agreement containing sufficient terms to be complete. Having conveyed real estate by sufficient deed, and without reservation of the crops, the grantor cannot show an oral agreement reserving the unsevered crops and shrubbery which by law pass with the land. Damery v. Ferguson, 48 Ill. App. 224 (1892); Smith v. Price, 39 Ill. 29 ( 1865$)$. A grantee cannot show an oral agreement that a portion of the purchase price for land was to be refunded if a survey found the acreage to be less than stated, when the contract contained a fixed price and the land was described both by its legal 
an agency contract silent only as to its duration is a complete written obligation since the tenure supplied by law is at the will of the parties. ${ }^{3 x}$

The description of the first aspect has shown that for the purpose of the parol evidence rule's becoming operative, contracts are divided into two classes. One is composed of writings embodying enough terms to constitute a complete obligation. The other is composed of agreements in any other form. While the rule operates to exclude agreements tending to alter the legal obligation in the former but not in the latter class, it has also been shown that parol agreements tending to vary written terms in incomplete writings were similarly excluded, but for another reason not yet examined. ${ }^{32}$

Yet there is nothing cosmic about the magic of the writing which prohibits the parties from changing their minds after the document has been executed. So there is no problem in admitting evidence to show a subsequent agreement. ${ }^{33}$ With respect to the rule's temporal limitation, the agreements which remain to be excluded must be those made prior to the instrument. By definition, the written terms represent the final agreement about those terms and all prior agreements pertaining to the written terms must be excluded. The subsequent agreement always controls. And it is for this reason that the written terms, even those of an incomplete obligation, cannot be varied. ${ }^{34}$ There remain only prior agreements pertaining to terms not expressed in a complete writing to be excluded because of the parol evidence rule. ${ }^{35}$

designation and by acreage, because by law the legal designation controls. Hill v. Hatfield, 72 Ill. App. 534 ( 1897 ). But cf. Ludeke v. Sutherland, 87 Ill. 48I (1877). Since implications of law can be negated by agreement, Sterling-Midland Coal Co. v. Great Lakes Coal \& Coke Co., 334 IIl. 28I, r65 N.E. 793 ( 1929 ), and since parol testimony of the negation is not admissible to alter a written obligation, the implication of law must have been treated as if it were a written term.

3x Union Special Sewing Machine Co. v. Lockwood, rro Ill. App. 387 (1903).

${ }^{2}$ See discussion in note 26 supra.

${ }_{33}$ "It is competent to show by parol a subsequent verbal change, modification or discharge of a written contract. ..." Redden v. Inman, 6 Ill. App. 55, 59 (1880). Accord: Lyon \& Healy, Inc. v. Central States Hotel Co., 296 Ill. App. 245 , I6 N.E. 2d 155 (r938).

$34 \mathrm{~A}$ term may of course refer to some prior negotiation in which case the writing will be qualified to that extent. Durham v. Gill, 48 Ill. I5I (x869); Gage v. Cameron, 212 Ill. 146 , 72 N.E. 204 ( 1904$)$.

35 It is no exception to this conclusion "that the rule only applies to unexecuted parol agreements." Warder, Bushnell \& Glessner Co. v. Arnold, 75 Ill. App. 674, 675 (I897). Facts similar to the Warder case are presented in Wood v. Dillon, 329 Ill. App. I6, 66 N.E. 2d 743 (1946) and Robbins v. Conway, 92 Ill. App. I73 (rgoo), but there was no discussion of this point.

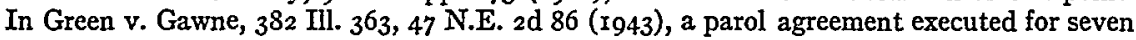
years was treated as if it were prior and unexecuted. While an executed agreement is, at its origin, a prior agreement, its execution occurs subsequent to the signing of the document, and it is treated like any other new and subsequent agreement and thus becomes admissible under the parol evidence rule. Gault v. Hunt, r83 Ill. App. 77 (rgr3) (semble).

Some agreements chronologically subsequent have been in issue under the parol evidence rule which required that they be labeled as prior or contemporaneous agreements. Ryan v. Cooke, I72 Ill. 302 , 50 N.E. $21_{3}$ (1898); Cooney v. Murray, 45 Ill. App. 463 (1892). 
If the intended function of writing within the commercial world is to be accurately reflected by the law, then upon the introduction of a complete written obligation, the legal concept ought to make inadmissible any evidence of prior agreements for the same transaction tending to add a term to the writing. The statement as found in the decisions is "[i]f it imports on its face to be a complete expression of the whole agreement, - that is, contains such language as imports a complete legal obligation,-it is to be presumed that the parties introduced into it every material item and term, and parol evidence cannot be admitted to add another term to the agreement although the writing contains nothing on this particular term to which the parol evidence is directed." ${ }^{36}$ This is not merely the most accurate and significant way to describe the function of writing as a legal concept. It makes the results of the parol evidence decisions consistent.

Yet, the writers have described the rule differently. Professor Sharp has said that "[ $t]$ he court indeed first considers whether it is sensible to suppose that such a collateral understanding in view of all the circumstances might in fact have been made and not superseded by the writing." ${ }^{37}$ If it is sensible to suppose that the parol agreement was made and not superseded by the writing whenever the writing is an incomplete obligation, this is a restatement of the concept previously derived. But taken in its ordinary sense, Professor Sharp's statement is a difficult test.

$3^{6}$ Armstrong Paint Works v. Continental Can Co., 301 Ill. I02, I06, I33 N.E. 7II, 7I3 (I922). A less articulate statement is that "prior parol agreements are inadmissible to vary, contradict or add to the terms of a written contract." Baltimore and Ohio R. Co. v. Brant, I7 III. App. I5I, X53 (I885). See also Jones v. Aetna Ins. Co., 226 Ill. App. x60 (xg22). A second form is that prior parol agreements are inadmissible to impair the legal effect of a written agreement. Smith v. Price, 39 Ill. 29 (I865). An early description of the rule was that contracts cannot rest partly in writing and partly in parol. Lane v. Sharpe, 4 Ill. 566 (I842); O'Reer v. Strong, I3 Ill. 688 ( 1852 ); Wear v. Parish, 26 Ill. 240 (r86r); Hartford Fire Ins. Co. v. Webster, 69 Ill. 392 ( 1873 ); Wood v. Surrells, 89 Ill. I07 (I878); Graham v. Eiszner, 28 Ill. App. 269 (I888); Cooney v. Murray, 45 Ill. App. 463 (I892); Over v. Walzer, Io3 Ill. App. Io4 (Igo2). During this same period, however, the decisions, in effect, repudiated this rule by admitting parol agreements wherever an incomplete writing was found. Ludeke v. Sutherland, $87 \mathrm{Ill} .48 \mathrm{I}$ (I87I); Millers' Nat'l Ins. Co. v. Kinneard, 35 Ill. App. I05 (I889); Durham v. Lathrop, 95 Ill. App. 429 (IgOO).

${ }^{37}$ Sharp, Promissory Liability, 7 Univ. Chi. L. Rev. I, 8 (I939). Cited in support of this formulation are Mitchell v. Lath, 247 N.Y. 377, I60 N.E. 646 (I928) and Danielson v. Bank of Scandinavia, 201 Wis. $392,23 \circ$ N.W. 83 ( 1930 ). The Mitchell case involved a complete written contract for the sale of real estate. The plaintiff sought to add an oral agreement (based on the same consideration) to the effect that an ice house belonging to the seller and located on another's property adjacent to the land being purchased was to be removed. The offer of proof was inadmissible. The Danielson case involved the sale of a mortgage evidenced by a writing that contained only a receipt of the price, the interest rate, and a promise by the seller to keep the mortgage instrument in his vault for the buyer. To this incomplete writing the court admitted evidence to show an oral agreement requiring the seller to refund the purchase price if the buyer were not satisfied. Properly interpreted as precedent, these cases support the theme of this comment as well as any cases which could be cited. See Goodhart, Determining the Ratio Decidendi of a Case, 40 Yale I.J. I6I (1930). The language in these decisions and the conclusion which was properly drawn from the language by Professor Sharp are considered on p. 357 infra. 
None of the agreements excluded by the court require any imagination to suppose that they could have been made. And the difficulty with inquiring whether it is sensible to suppose the agreement was made is that, if properly determined, proof of any parol agreement would not be excluded. For a court which thinks the agreement was made has really decided that if the party were given an opportunity, he could probably prove the agreement. The contrary is true of a court believing that it is not plausible to suppose the agreement was made. The process of predicting whether or not the agreement can be proved has nothing to recommend it when the same conclusion can be accurately and reliably reached by the adversary proceeding. So this aspect of the test simply advocates that the parol evidence rule ought not to exist and is of no help in explaining the decisions.

The remaining question of this test is whether it is plausible that the writing did or did not supersede the parol understanding. If "supersede" means that subsequent agreements control prior ones about the same term, the test would exclude any attempt to vary a written term by parol evidence of a prior agreement. But it has been shown that this result is not necessarily attributable to the parol evidence rule. If Professor Sharp's test is to apply as the parol evidence rule, it must encompass the case in which an attempt is made to add a term to the writing. To this extent, the second aspect of the test is difficult to apply.

If the court is to ask the parties whether they intended by the writing to supersede the parol agreement, the party offering to show the agreement undoubtedly will answer negatively. The other party undoubtedly will answer affirmatively. So this is not a very useful inquiry. The writing, which by definition does not embody the term, will not help unless the court is interested in the completeness of the writing. But this would be to take the test in its broadest meaning - a restatement of the rule derived from the function of writing. It can always be urged that the court could look at the circumstances of the case. But having looked, the court is no closer to a decision. It has not been told what circumstances are to be controlling. Thus, if taken in any but its broadest sense, Professor Sharp's rule is an unworkable one.

For Wigmore, the rule is "that when the parties have embodied a transaction in a single document, the writing is indisputable as to the terms of the transaction. ..." ${ }^{38}$ In simple language, the rule is that when all the terms are in a writing, the writing contains all the terms. Nothing can be gained by accepting an offer to prove another term when by definition it does not exist. But in every case the contention is that all the terms are not in the writing. A rule which supplies the basis for deciding cases which never arise is not a very useful rule.

A cursory examination of the cases shows that the question is not whether a party has sufficient proof, but whether the court ought to listen to the proof at all. To make this rule applicable to this question, it was given a mystic name,

${ }^{38} 9$ Wigmore, Evidence $\$ 2426$ (3d ed., 1940) at 79. 
integration, ${ }^{39}$ and the question in those terms became whether the parties intended to integrate their agreement. $4^{\circ}$ When the parties are asked whether they intended to embody all the terms in the writing, the one offering to prove the agreement will answer negatively and the other will answer affirmatively. If the alleged agreement were not in fact made, then there are no other terms of the transaction. The affirmative answer is right and the other is meaningless. The offer of proof will be rejected. If the alleged agreement were in fact made, then there is another term to the transaction, and since the question is designed to give effect to their intent, both parties by their answers will require that the agreement be enforced. It is the intent of the one giving the affirmative answer that all terms be embodied in the writing and thus to embody the one in question. The other party did not intend to embody the term in the writing and thus intended it to be operative in addition to the terms in the writing.

The ultimate determination of this question depends upon whether a party has sufficient evidence to support his allegation. The rule cannot help the court decide whether to hear the proof in the first instance. So if this were the rule, the result of its application would be no result at all.

Having offered a rule which is a truism and a criterion which involves no alternative, Wigmore offers another test. No longer interested in the actual intent, "the chief and most satisfactory index for the judge is found in the circumstance whether or not the particular element of the alleged extrinsic negotia-

${ }^{39}$ The "process of embodying the terms of a jural act in a single memorial may be termed the Integration of the act. ..." Tbid., $\$ 2425$ at 76 . The integration theory has been adopted in Air Conditioning Corp. v. Honaker, 296 Ill. App. 22I, I6 N.E. 2d I53 (1938); 3 Corbin, Contracts $\$ 573$ (Ist ed., I95I) at 216 . Wigmore points out that the single memorial may be oral as well as written so that the rule would apply to oral integration. He relies entirely for this view upon Gilbert \& Co. v. McGinnis, $x_{4}$ Ill. 28,28 N.E. 382 (I885). In that case, the terms of an oral agreement provided that the buyer advance money from time to time on a crop contract. The buyer subsequently refused to advance money unless the seller would execute a note. The seller refused to execute the note and informed the buyer that the crops would not be delivered when due. The buyer offered to show a trade custom that notes were to be given in this situation. Because a trade custom may only be shown to explain an ambiguous term and because the court found the term to be clear, the offer were rejected. The court said "[t]he rule ... is equally applicable to a verbal contract, where the terms of it are definitely fixed, as they are in the present case." Ibid., at 33,383 . It is this statement which is quoted by Wigmore in support of his point. 9 Wigmore, Evidence $\$ 2425$ (3d ed., r940) at 79 n. 5. Yet the evidence excluded was not a parol agreement. The rule in the quotation was not the rule of integration by which the court seeks to determine whether the parties intended to embody all the terms in a single utterance. It was conceded that there were no additional terms and this was an attempt to vary the plain meaning of a term by a trade custom which Wigmore declares to be outside the scope of the integration question. Ibid., $\$ 2464$ at $21 \mathrm{r}$.

${ }_{40}$ "The fundamental question is as to the intent of the parties to restrict the writing to specific elements or subjects of negotiation ... and if that intent existed, then the other subjects . . . can be established. ..." 9 Wigmore, Evidence $\$ 243$ I (3d ed., r940) at ro2. The contrary and controlling notion for the courts is that "the contentions of the parties to the contract are not the criterion which should guide the court in determining whether the written contract is a full expression of the agreement of the parties. The court must determine this from the writing itself." Armstrong Paint Works v. Continental Can Co., 30r Ill. 102, ro6, I33 N.E. 7II, 7I3 (I922). 
tion is dealt with at all in the writing." $4 \mathrm{4}$ This test, for example, operates to exclude a parol agreement that would require a maximum ash content for coal when the writing specified the screening size, because the writing has dealt with the quality of the coal..$^{2}$ It operates to exclude every agreement tending to vary a term of the writing. Yet, it has been shown that this result is not attributable to the parol evidence rule but to the fact that subsequent agreements control prior ones. If the parol evidence rule does any thing it must exclude parol agreements adding terms to the writing and this test would always admit them.

Wigmore offers a final method of ascertaining the parties' intention to integrate which is similar to the subject matter test. The rule should be applied "only after a comparison of the kind of transaction, the terms of the document, and the circumstances of the parties." 43 Yet without more, a comparison of these elements cannot lead to a conclusion that the parties have or have not intended to integrate their agreement. The test is an enthymeme.

Wigmore has offered nothing to explain the decisions under the parol evidence rule. He has criticized the only legal concept which can account for the results and which can be derived from the function of writing in the commercial world. $\mathrm{He}$ has said that the "conception of a writing as wholly and intrinsically selfdeterminative of the parties' intent . . . is an impossible one." ${ }_{44}$ And yet he believes that writing does more than replace witnesses as a mode of proof. The writing for Wigmore "is the act, not merely one of the possible ways of proving the act." ${ }_{45}$ This is to say that "[t]he writing itself is operative. .. ." ${ }_{46}^{6}$ This is the conclusion which was here reached after examining the relationship of the delivery doctrine to the parol evidence rule. The conclusion was that the writing had significance of its own and upon delivery was more important than the actual obligation. This is the magic of writing which formed the principal notion of the parol evidence rule. So Wigmore can now be seen as an advocate of the legal concept he sought to condemn-a rule which makes evidence of prior parol agreements inadmissible to alter a complete legal obligation in writing.

\section{III}

The effect of writing upon the determination of contract obligations has been analyzed with respect to the admissibility of parol agreements. It is impossible to decide the admissibility question or to define the obligation until the written terms have been interpreted. So the parol evidence rule involves both the selection and the interpretation of contractual terms.

${ }_{42} 9$ Wigmore, Evidence $\$ 243^{\circ}$ ( 3 d ed., x940) at 98. (1929).

${ }_{42}$ Sterling-Midland Coal Co. v. Great Lakes Coal \& Coke Co., 334 Ill. 28I, r65 N.E. 793

${ }^{43} 9$ Wigmore, Evidence $\S 2442$ (3d ed., 1940) at $\mathrm{r}_{32}$.

44 Tbid., $\$ 243$ I at ro3.

45 Ibid., $\$ 2426$ at 87 . Note that Wigmore also asserted that "a writing is, of itself alone considered, nothing,- simply nothing." Tbid., § 2400 at 5 .

${ }^{46} \mathrm{Ibid} ., 82426$ at 87 . 
The interpretation aspect is stated as a rule which admits parol evidence to explain ambiguous terms. ${ }^{47}$ In the sense that most words have more than one meaning, ambiguity is always present. The result of using this definition would be to make the parol evidence rule completely ineffective. So an ambiguous term must be one for which the appropriate meaning is not clear.

The search for appropriate meanings is the function of the objective theory. The appropriate meaning for this theory is the one upon which the promisee may reasonably rely. It involves the standard of the reasonable man. The rule about trade usage, for example, describes the framework of knowledge within which he selects the appropriate meaning. When a term is ambiguous within its written context, trade usage is admissible, and if the meaning is then clear, no further parol evidence may be received..$^{8} \mathrm{But}$ if there is no usage to explain an ambiguous term, then parol evidence is admissible. 49 Where a term is clear within its written context, usage is nevertheless admitted ${ }^{\circ}$ unless it has been negated by agreement appearing in the writing. ${ }^{.5}$

Since usage may always be shown unless it is expressly negated, it is apparent that commercial understandings are part of the framework for interpreting contracts. The rule which admits parol evidence to explain ambiguities does so when the written context and the commercial understandings are unable to provide meaning for which there is no likely alternative. The doctrine about interpretation for the parol evidence rule is therefore the objective theory.

It was shown.that to the extent the parol evidence rule selects terms, the rule is based upon a commercial understanding about the significance of writing. The rule about trade usage has shown that commercial understandings are included within the framework in which the objective theory determines contract obligations. Consequently, the rule about trade usage has shown that it was the objective theory which actually excluded evidence of prior parol agreements to add a term to a complete writing. ${ }^{2}$ (1922).

${ }_{47}$ See, e.g., Armstrong Paint Works v. Continental Can Co., 30r Ill. ro2, r33 N.E. 7II

$4^{8}$ Chicago Portland Cement Co. v. Hofman, I68 Ill. App. 7r (Igr2); Packard v. Van Schoick, 58 Ill. 79 (187r).

49 Air Conditioning Corp. v. Honaker, 296 Ill. App. 221, I6 N.E. 2d 153 (1938).

$5^{\circ}$ Leavitt v. Kennicott, ${ }_{57}$ Ill. 235, 4 I N.E. 737 ( 1895 ). The court in Steidtman v. Joseph Lay Co., 234 Ill. $84,88,84$ N.E. 640,642 (Ig08) stated that "' $t$ ] ${ }^{2}$ he testimony of witnesses is admissible to explain not only technical words of art or science, but words or phrases having a local meaning or a special meaning in a particular calling, trade, business or profession."

${ }_{5 x}$ Winnesheik Ins. Co. v. Holzgrafe, 53 Ill. $5^{16}$ (1870); First Trust \& Savings Bank v. Economical Drug Co., 250 Ill. App. II2 (I928); Gilbert \& Co. v. McGinnis, II4 Ill. 28, 28 N.E. 382 (I885).

52 See the opinion of Frank, J. in Zell v. American Seating Co., I38 F. 2d 64I (C.A. 2d, I943), rev'd 322 U.S. 709 (r944). Note, however, that some of the writers have supported the position that objective theory requires that mutual expressed understanding about the meaning of any words be given effect despite the fact that the words have a different meaning in the writing. See, e.g., Grene, Theories of Interpretation in the Law of Contracts, 6 Univ. Chi. L. Rev. 374 (r939). 
Since it is really the objective theory which selects as well as interprets the terms of a contract when writing is involved, the place of the parol evidence rule in the law of contracts is clear. It is a restatement of the objective theory for a select group of cases.

\section{CONTRACTION OF FEDERAI JURISDICTION: CONVENIENCE OR NECESSITY?}

While events national and international do steadily press our people into a closer union, the national courts alone make their possibly gallant, but surely eventually futile, attempts to restore states-rightism.

-CLARK, J.

Thus did one of the nation's eminent jurists rebuke a majority of his court for a new contraction of federal jurisdiction in favor of state courts. The national courts do seem to be making an effort to contract their jurisdiction, if not to "restore states-rightism." Arguably, the greatly increased scope of federal activities may warrant such a result. Federal dockets are overcrowded with cases arising under federal statutes. Part of the total burden could be removed by deferring to the state courts in specific areas. Such action might make for greater harmony between the two systems and add to the dignity of the federal courts. ${ }^{2}$ Congressional determination of federal jurisdiction, however, sets a definite limit on the extent to which federal courts may contract their jurisdiction in accordance with their own views of convenience and the federal-state relationship.

A contraction of federal jurisdiction may be desirable in certain situations

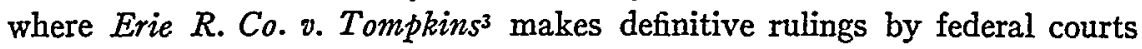
impossible. In cases where its jurisdiction is based solely on diversity of citizenship, a federal court, under the Erie doctrine, must look to the law of the state in which it sits for its rules of decision (except for questions involving the federal constitution or statutes). Even when the rule of the state is unsettled, the federal court must still, in theory at least, apply what it finds the state law to be. ${ }^{4}$ Unlike the case of a state court's ruling on a federal question, however, a federal court's determination of state law cannot be appealed to the state supreme court. An anomalous situation may arise in which a state issue is adjudicated by the federal court, only to be decided differently thereafter in the state

× Beiersdorf v. McGohey, I87 F. 2d 14, I7 (C.A. 2d, I951).

${ }^{2}$ Frankfurter, Distribution of Judicial Power Between the United States and State Courts, I3 Cornell L.Q. 499 (I928).

${ }^{3} 304$ U.S. 64 ( 1938 ).

4 Cities Service Oil Co. v. Dunlap, 308 U.S. 208 (I939); McClare v. Mouton, I23 F. $2 d 45^{\circ}$ (C.A. Ioth, I94I); Federal Court's Disposition of Unsettled Questions of State Law, How a Federal Court Determines State Law, 48 Col. L. Rev. 575 (1948); How a Federal Court Determines State Law, 59 Harv. L. Rev. 1299 (1946). 